\title{
The First Probable Case of Leprosy in Southeast Italy (13th-14th Centuries AD, Montecorvino, Puglia)
}

\author{
Mauro Rubini, ${ }^{1,2}$ Valentina Dell'Anno, ${ }^{2}$ Roberta Giuliani, ${ }^{2}$ Pasquale Favia, ${ }^{2}$ and Paola Zaio ${ }^{1}$ \\ ${ }^{1}$ Anthropological Service, SBAL, Via Pompeo Magno 2, 00193 Rome, Italy \\ ${ }^{2}$ Department of Archaeology, Foggia University, Piazza Civitella 2, 71121 Foggia, Italy
}

Correspondence should be addressed to Mauro Rubini, antropologiasal@libero.it

Received 21 March 2012; Revised 3 June 2012; Accepted 25 June 2012

Academic Editor: Scott M. Fitzpatrick

Copyright ( 2012 Mauro Rubini et al. This is an open access article distributed under the Creative Commons Attribution License, which permits unrestricted use, distribution, and reproduction in any medium, provided the original work is properly cited.

\begin{abstract}
In 2008, during an archaeological excavation on the medieval site of Montecorvino (Foggia, Puglia, Italy), ten individuals were found buried near the principal church. The tombs were dated to the 13th-14th centuries AD, except for one attributable to the 11th century AD. The individual from tomb MCV2 shows some bone changes in the rhinomaxillary area. The most probable diagnosis is that she suffered from a type of near-multibacillary leprosy. Although leprosy has been documented in Italy from the first millennium $\mathrm{BC}$ and well described in the first millennium $\mathrm{AD}$, its presence seems to be confined to Northern and Central Italy. This is the first case of leprosy in southeastern Italy and the second in Southern Italy overall. At the moment, the interesting datum is that leprosy seems to appear in Southern Italy only after the first millennium AD. All this could be because of the First Crusade with the opening of new trade and pilgrimage routes to the Near East or simply because other cases of leprosy have still not been found in osteoarchaeological context.
\end{abstract}

\section{Introduction}

Leprosy, or Hansen's disease, is a chronic infection caused by an unculturable pathogen, Mycobacterium leprae. It affects the peripheral nervous system primarily, especially the extremities (neural leprosy), and secondarily involves the skin, nasal tissues, and bones [1]. As is well known, Mycobacterium leprae is a highly infective bacterium with low pathogenicity; that is, its ability to induce clinical disease is low [2]. The bacteria affect the motor, sensory, and autonomic nervous systems. $M$. leprae accumulates principally in the extremities of the body, where it resides within the macrophages and infects the Schwann cells of the peripheral nervous system. Lack of myelin production by infected Schwann cells and their destruction by host-mediated immune reactions lead to nerve damage, sensory loss, and the disfiguration that, sadly, are the hallmarks of leprosy [3]. Primary transmission occurs through droplet infection [4]. The incubation period is very long (in some cases 20 years) before clinical signs and symptoms become apparent [5]. Leprosy can affect all age groups and seem to prefer male sex, although it is often first observed before the age of 20 and over $60[6,7]$. Response to the disease is highly variable, and the immune status of each infected person determines the type and severity of pathological change [8]. In its most severe form, multibacillary (MeSh-lepromatous) leprosy, both the skin lesions and the peripheral nerve damage become generalised and symmetrical in nature. Those with high immune status are more likely to develop paucibacillary (MeSh-tuberculoid) leprosy, where only a small number of skin lesions develop and peripheral nerve damage is asymmetrical. Having reached endemic status in mediaeval Europe, leprosy declined in the postmediaeval period about the 14th century $\mathrm{AD}$ [9-11]. The decline of leprosy in Western Europe implied a complex web of factors, especially medical, environmental, social, and legal [12]. Under the biomedical aspect, this decline probably may have been caused by the cross-infection between leprosy and tuberculosis [13-15], although this possibility is debate still today and, the exact relationship between TB and leprosy still remains unclear [16].

In Italy, the skeletal documentation on leprosy is scarce. According to the osteoarchaeological evidence, it was present in the Northeast in the first millennium BC [17], in Central 


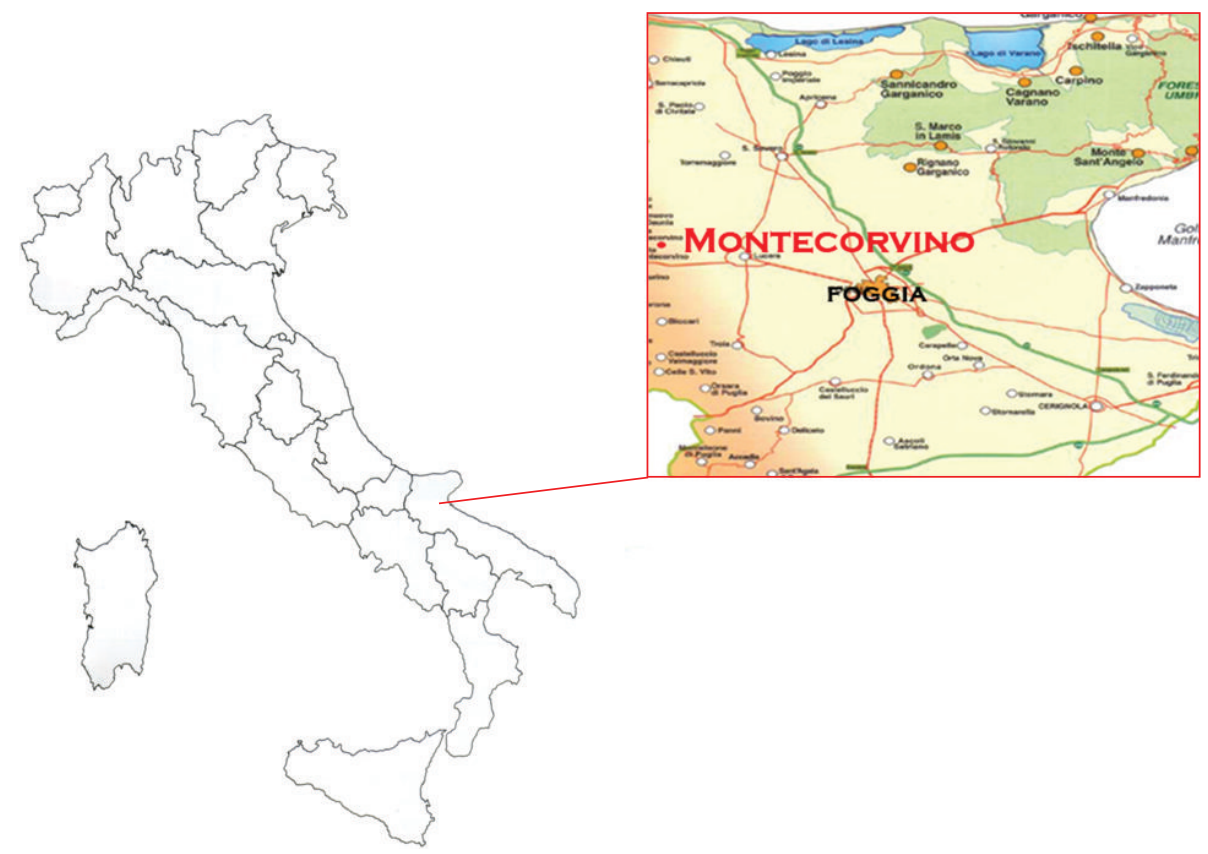

FIGURE 1: Geographic location of the site.

Italy during the Roman period near Rome with the cases of Palombara [18] and Martellona [19] and in the early Middle Ages with the cases of Campochiaro Vicenne [20] and Campochiaro Morrione [21]. Furthermore, there is another late medieval case in South Italy [22].

Leprosy is rarely found today in Europe but is still a significant disease worldwide, principally in Southeast Asia, Africa, and South America (Brazil) [23]. The aim of this study is to investigate and discuss the skeleton of an individual from the medieval church of Montecorvino that shows interesting rhinomaxillary changes.

\section{Material and Methods}

In 2008, during an archaeological excavation in the mediaeval town of Montecorvino (Foggia, Puglia-Figure 1), ten skeletons were found buried in graves near the principal church. The chronology obtained from the gravegoods is 13th-14th century $\mathrm{AD}$, except for one dated to the 11th century AD. The skeleton under study was found in a tomb that was built with bricks near the perimetral wall of the church (Figure 2) and was found without covering. The code number of this individual is MCV2. The only object found with it is an iron belt-buckle, which was dated by its particular shape to the end of the 13th century AD (Favia, personal communication). The skeletal remains are quite well preserved but unfortunately incomplete (Figure 3). The diagnosis of sex and age at death was carried out according to the standard suggested by Buikstra and Ubelaker [24]. In particular, sex determined by the morphology of the os coxae [25-27] and cranium [28]. Age at death was calculated on the morphological changes of the pubic symphyseal face [29], on the auricular surface of the os coxae [30] and on the cranial suture closure [31]. The screening of the traces of leprosy

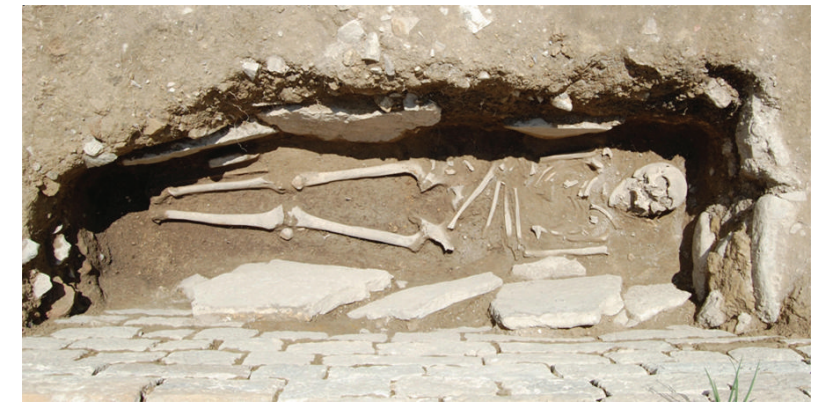

Figure 2: Tomb MCV2.

on the skeleton was effected according to the suggestions of Andersen and Manchester [32], Roberts and Manchester [33], and Nunzi, and Massone [5].

\section{Description of the Skeleton}

MCV2 is a skeleton attributable to a female aged 35-40 years. The examination of the skeletal remains shows some bone changes in the rhinomaxillary region. The alveolar process of the maxilla shows an intense erosive activity in the anterior side with loss of bony tissue producing the exposure of the cavity of the root of the left and right central incisors and right lateral incisors, which are all absent (see Figure 4(a)). The loss of teeth was surely antemortem because the alveolar cavities show a discrete atrophy. In the left side, a damage postmortem is present in the alveolar portion of the lateral incisor and canine. Although the area is damaged in the left side, the anterior nasal spine could be resorbed (see Figure 5(a)) because of visible traces of little bone neoformation. There is a symmetrical resorption and remodelling of 


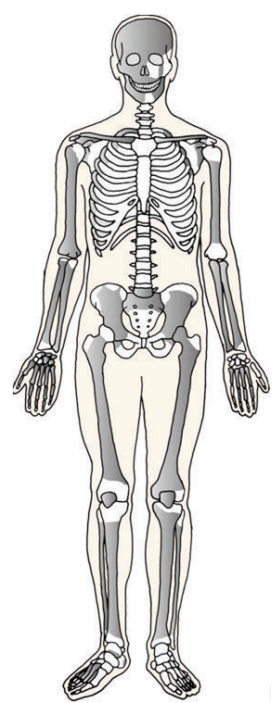

Figure 3: Bones present (grey) in individual MCV2.

the normally sharply defined inferior margins of the piriform aperture with irregular rounding of the external profile (see Figure 5(a)), while the internal nasal surface is pitted (Figure 4(b)). The right lateral margin is smooth and thick in appearance, while the left is damaged. Furthermore, the left and right inferior nasal conchae were partially resorbed. In conjunction with the remodelling of the margins of the nasal aperture, the alterations of the intranasal structures (that are not damaged) seem in the appearance of a wide, semiempty cavity (see Figure 5(a)). The alveoli of the anterior teeth shows an irregular shape in the lingual edge, and in the hard palate there is an intense presence of pitting that involves also the alveolar cavity of the right and left molars (Figure 5(b)). In the postcranial skeleton only a light periostitis is present on the tibiae in mesiodistal position.

\section{Differential Diagnosis}

There are various pathological conditions that could lead to the destruction of bone in the rhinomaxillary region [34]. These disorders include granulomatous diseases such as sarcoidosis and treponemal diseases and fungal infections such as aspergillosis and mucormycosis (phycomycossis), actinomycosis (a bacterial rather than a true fungal disease), and lupus vulgaris (tuberculosis of the facial skin and soft tissue).

Sarcoidosis is a granulomatous disease of unknown aetiology. Like leprosy, it tends to affect the phalanges of the fingers and toes, causing lytic lesions and no reactive bone formation [34]. However, in the skull, it causes mainly the destruction of the nasal bones while only rarely of the anterior nasal spine and never of the crest [35]. Thus, we can exclude this disease as an explanation for the bony lesions in our specimen. In view of the reconsideration of the origin of treponemal disease in the Old World, we may also discuss this group of pathologies since, like leprosy, they can lead to the destruction of the nose and to bony changes in the lower limbs [34]. Treponemal diseases include syphilis (venereal and endemic), yaws and pinta, which are granulomatous

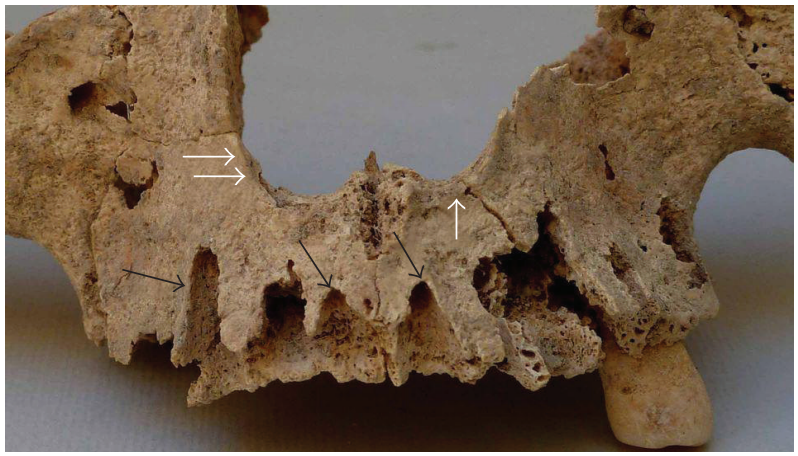

(a)

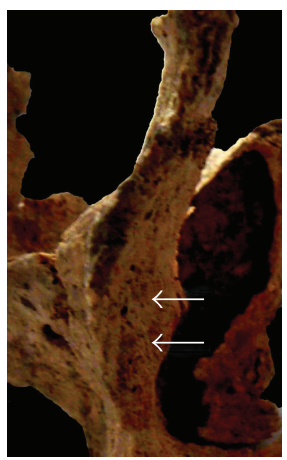

(b)

FIGURE 4: (a) Alveolar process of the maxilla with an intense erosive process in anterior part and loss of bony tissue with exposure of the tooth roots in the right side and of the left central incisor (black arrows). Furthermore, the margins of the piriform aperture are rounded (white arrows). (b) Particular of the nasal cavity. On the bony wall there is presence of pitting (arrows).

infections caused by spirochetes of the genus Treponema. Excluding pinta, which does not affect bones, in the tertiary stage these diseases can involves the skeleton, and they tend to be associated with inflammatory bony changes accompanied by extensive bone regeneration, often resulting in alteration of the bone morphology and in some cases destruction of the nasal-palatal area may occur [34]. Yaws is typical of the humid tropical regions of South America, Africa, Asia, and Oceania. In this disorder, the last stage can be characterized by widespread bone, joint, and soft tissue destruction, which may include extensive destruction of the bone and cartilage of the nose (rhinopharyngitis mutilans or "gangosa"). Joints may stiffen, and chronic osteitis and periostitis can lead to deformed leg bones (sabre tibiae). Bejel (endemic syphilis) is present in nomadic populations of the Sahel and more in general in the desert region of Africa, in the Middle East, Central Australia, and Asia. Periostitis of the leg bones is commonly seen. The involvement of the skull is very rare, with gummas of the soft palate and nose developing in the last stage [35]. The "gangosa" condition may occur rarely. In venereal syphilis, the most commonly affected bones are (in order of importance) tibia, frontal and parietal (with caries sicca on the outer tables), nasal-palatal region, clavicle, sternum, vertebrae, fibula, femur, humerus and radius, and 


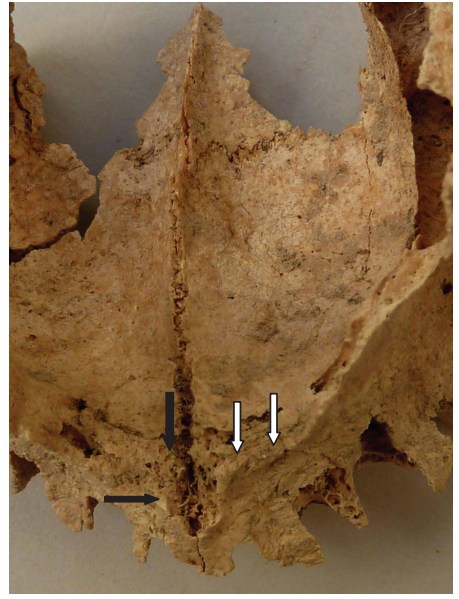

(a)

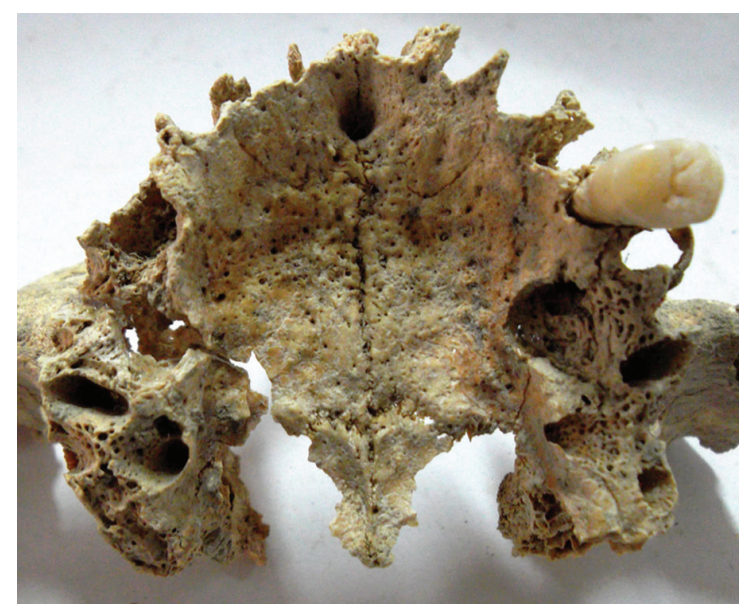

(b)

Figure 5: (a) Particular of the possible resorption of the anterior nasal spine with bone neoformation (black arrows) in the right part (the left is partially damaged) and remodelling of the margins of the nasal aperture with presence of bony neoformation (white arrows). (b) Hard palate. On the surface an intense pitting process is present that involve also the alveolar cavity of the left and right molars.

ulna. The teeth may also be involved, showing a screwdriver shape (Hutchinson teeth). No specific involvement of the feet is observed in this pathology [34, 35]. The most common bones afflicted during the tertiary stage of the disease are the tibia (with sabre-shaped deformity) and the skull. According to Ortner [34], the calvarial lesions are the most specific diagnostic features. Although the nasal cavity is often enlarged, producing the characteristic "saddle nose," the nasal spine is usually spared [36]. Furthermore, the anterior alveolar change process is uncommon in yaws and syphilis [37, page 297]. Therefore, the pathogenetic picture of our skeleton does not correspond to that of treponemal diseases.

Aspergillosis is marked by inflammatory granulomatous lesions in the skin, ear, orbit, nasal sinuses, lungs, and sometimes bones and meninges. It affects the paranasal sinuses and orbit or the anterior cranial fossa [35].
Mucormycosis (phycomicosysis) is a rare invasive fungal infection, which tends to affect people who have poorly controlled diabetes. It results in black, dead tissue in the nasal cavity and blocks in the blood supply to the brain, leading to neurological symptoms, such as headaches and blindness [38]. Mucormycosis attacks the nasal cavity with involvement of the paranasal sinuses and their walls [34].

A diagnosis of aspergillosis and mucormycosis can be ruled out, because in no case is the unilateral and bilateral perforation of the hard palate present. Furthermore, no traces of this pathology are present in the orbit region of the Montecorvino skeleton.

Actinomycosis produces effects on the cervicofacial area; bone involvement is rare. When affected, the mandible rather than the maxilla is more involved $[34,39]$. This is not the case with our individual.

Lupus vulgaris is a chronic tubercular infection of the skin involving soft yellow swellings, ulcers, and abscesses. Long-standing tuberculosis of the facial skin and soft tissues can lead to the destruction of the nasal bones [35]. The anterior alveolar process, however, is rarely affected [37], which discounts lupus vulgaris as a diagnosis.

Given the localization of the lesions in our sample, the most likely diagnosis is multibacillary leprosy [32, 33, 37, 40]. Some bone changes are present in the rhinomaxillary region. The enlargement and rounding of the piriform aperture, the cicatrisation of the lower margin of the inferior nasal aperture, and erosion of the alveolar margin accompanied by the loss of the front teeth could be changes seen in leprosy referred to as rhinomaxillary syndrome [32, page 122]. Although the area is damaged, also the resorption of the anterior nasal spine could be present. Furthermore, the presence of pitting shows a presence of a chronic inflammation in the nasal-palatal region. Deformity of the nasal-maxillary facial structures results from primary skeletal infection by $\mathrm{Myco-}$ bacterium leprae $[34,41]$, and alterations of the hands and feet (especially the fifth metatarsal bone, where the same nerves that enervate the fibula are present) are secondary to pathological changes in the peripheral nerves with consequent loss of sensory and motor functions [42]. These last osteological markers are not present in our sample, but a light periostitis in the lower limbs is present also if aspecific. Periostitis, also known as periostalgia, is a clinical condition caused by inflammation of the periosteum, a layer of connective tissue that surrounds bone. The condition is generally chronic and is marked by tenderness and swelling of the bone and an aching pain [35]. It could be due to scurvy, fractures, and infectious diseases such as, for example, treponematosis and leprosy [35]. In this case, in absence of fractures or scurvy it is probably secondary and associated with an infectious disease.

\section{Discussion and Conclusions}

The study of the pathological changes of the skeleton from the church at Montecorvino shows that this individual probably suffered from a type of near multibacillary leprosy. When leprosy affects the skeleton, a number of specific and nonspecific bony and osteoporotic changes occur during 


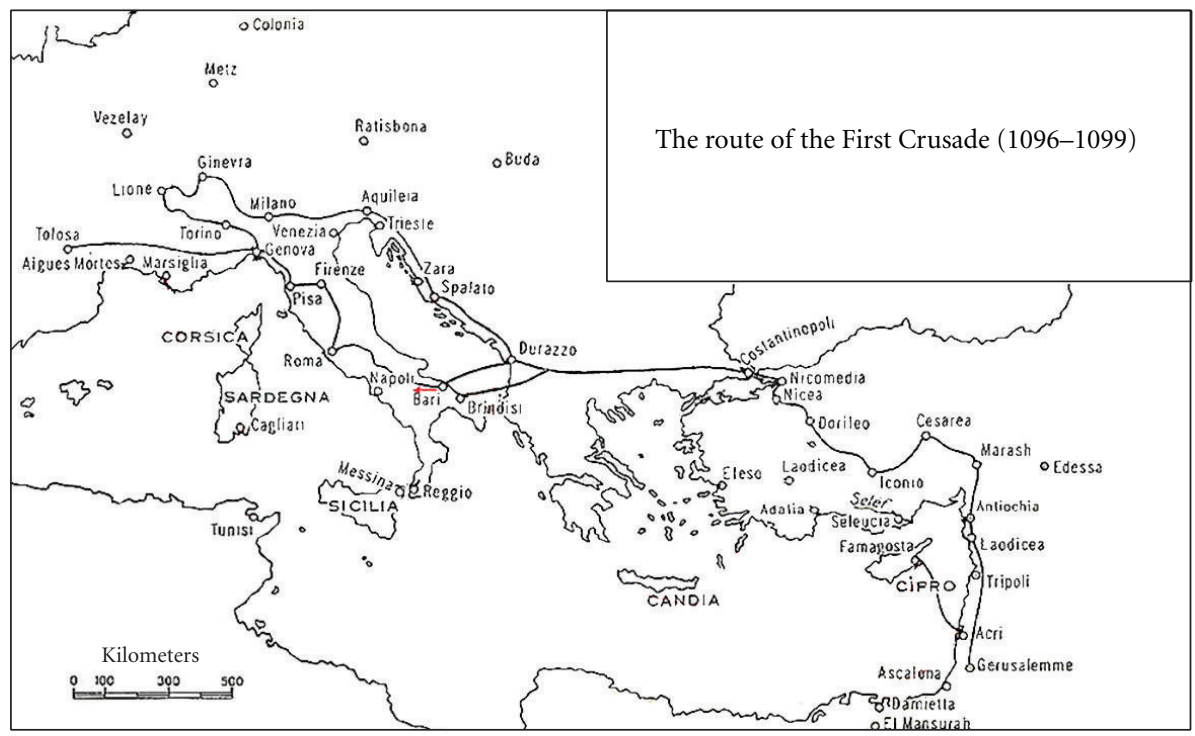

Figure 6: The route of the First Crusade (1096-1099).

pathogenesis [43]. Specific bony changes are caused by invasion of the tissues by $M$. leprae, which is why facial changes are seen; secondary bone changes are a result of peripheral nerve involvement (hands, feet and lower leg bones) and lead to sensory nerve anaesthesia, trauma to the hands and feet because people cannot feel the trauma, then ulceration of the feet and hands, then secondary infection of the bones of the hands and feet [5]. According to Nunzi and Massone [5], the major skeletal foci of leprosy are the face and small tubular bones of the hands and feet. Rarely also other bones may be affected [34]. The mediaeval individual from Montecorvino shows some traces of leprosy, with a possible rhinomaxillary syndrome. Although pathogenesis of the skeletal changes in leprosy is generally difficult to assess in osteoarchaeological remains, Ortner [34] observed that the presence of destructive and proliferative lesions could indicate the infectious phase (chronic or acute) of the disease, without specifying the pathological process that caused the bone changes. In fact, Mycobacterium leprae prefers cool environments, and the distribution of the lesions in multibacillary leprosy is associated with the cooler, exposed areas of the skin and mucous membranes like that within or under the nose or more generally of the face, which constitutes the elective site of aggression of the disease [1]. Leprosy does not cause death; rather, people usually die of TB $[13,14]$. Therefore, the different manifestations of the disease in osteoarchaeological remains are not homogeneous but can show numerous variants [34]. Furthermore, the last consideration is that MCV2 was buried in the normal cemeterial area of the church. This is not infrequent during this period. Usually individuals with leprosy were buried in normal cemetery $[9,20,21,44,45]$.

The mediaeval individual from Montecorvino is the first case of leprosy described in the literature in southeastern Italy (Puglia). It could be important in the geography of the spread of leprosy. In recent years, the description and publication of leprosy cases in Italy has increased (for a survey see [21]). During the first millennium AD, there are no osteological cases found in southern Italy, although many prehistoric and historic skeletal collections have been studied by anthropologists and palaeopathologists. At present, the most ancient cases known are that of Henry VII in Calabria (southwest Italy) dated to the thirteenth century AD [22] and now that of Montecorvino (southeast Italy) dated to the thirteenth-fourteenth century AD. The spread of leprosy in Southern Italy could be subsequent to the first wave that afflicted Northern and Central Italy during the first millennium $\mathrm{AD}$ [21]. In fact, during this period, the phenomenon of the "Migration of the Peoples" or barbarian invasions produced an increase in epidemic diseases in Italy [18]. An explanation for the presence of leprosy only in Northern and Central Italy in the first millennium AD could be found in the pattern of Monot et al. [46] based on the use of comparative genomics. Monot et al. demonstrated that the single clone responsible for leprosy can be traced by analysis of rare single-nucleotide polymorphisms (SNPs). They have obtained four permutations (types) of SNPs distributed throughout the world. According to these results, leprosy seem to have originated in eastern Africa or the Near East and spread with successive human migrations. According to the scheme of Monot et al., from about 40,000 years BP the disease's path was the same as that of the route of the human populations obtained from genetic and anthropological data and was directed from Central Asia/Eastern Europe to Western Europe [47]. This human flow would seem to be uninterrupted during the first millennium AD preferring terrestrial way [21]. This last observation could be confirmed by the geographical location of the Italian osteoarchaeological evidences.

After the first millennium AD, probably the crusades played an important role in the spread of leprosy in Italy. In particular, the route of the First Crusade (1096-1099) 
interested southeastern Italy (see Figure 6), and it opened an important trade and military route toward the Near East [48]. According to this hypothesis, leprosy present in North and Central Italy in the first millennium AD spread in the first centuries of the second millennium to the South, favoured by this great flow of soldiers, traders, clerics, and adventurers. On the other hand, the scarce evidences of leprosy in Italy permitted not a complete and exhaustive picture of its spread. Furthermore, the absence of osteoarchaeological evidences in South Italy before the second millennium $\mathrm{AD}$ could be casual and in the future, with the help of new findings, this picture could change.

\section{Acknowledgments}

The authors would like to thank Vittorio Cerroni, Scientific Technical Assistant of the Anthropology Laboratory of the S.B.A.L., for the graphic creations and figures, and Professor Archer Martin (American Academy in Rome/University of Cologne) for the English language revision of the paper.

\section{References}

[1] H. Choudhuri, D. M. Thappa, R. H. Kumar, and S. Elangovan, "Bone changes in leprosy patients with disabilities/deformities (A clinico-radiological correlation)," Indian Journal of Leprosy, vol. 71, no. 2, pp. 203-215, 1999.

[2] L. B. Adams, D. M. Scollard, N. A. Ray et al., "The study of Mycobacterium leprae infection in interferon- $\gamma$ gene-disrupted mice as a model to explore the immunopathologic spectrum of leprosy," Journal of Infectious Diseases, vol. 185, no. 1, supplement, pp. S1-S8, 2002.

[3] D. A. Hagge, S. O. Robinson, D. Scollard, G. McCormick, and D. L. Williams, "A new model for studying the effects of $\mathrm{Myco}$ bacterium leprae on Schwann cell and neuron interactions," Journal of Infectious Diseases, vol. 186, no. 9, pp. 1283-1296, 2002.

[4] B. K. Mandal, E. G. L. Wilkins, E. M. Dumbar, and R.T. Mayon White, Lecture Notes on Infectious Diseases, Blackwell Science, Oxford, UK, 1996.

[5] E. Nunzi and C. Massone, Note di Leprologia, AIFO, Bologna, Italy, 2009.

[6] D. Resnick, "Osteomyelitis, septic arthritis,and soft tissue infection: organisms," in Diagnosis of Bone and Joint Disorders, D. Resnick, Ed., vol. 3, pp. 2510-2624, 4th edition, 2002.

[7] W. H. Van Brakel, P. G. Nicholls, L. Das et al., "The INFIR Cohort Study: investigating prediction, detection and pathogenesis of neuropathy and reactions in leprosy. Methods and baseline results of a cohort of multibacillary leprosy patients in North India," Leprosy Review, vol. 76, no. 1, pp. 14-34, 2005.

[8] S. P. W. Kumarasinghe, M. P. Kumarasinghe, and U. T. P. Amarasinghe, "“Tap sign" in tuberculoid and borderline tuberculoid leprosy," International Journal of Leprosy and Other Mycobacterial Diseases, vol. 72, no. 3, pp. 291-295, 2004.

[9] K. Manchester, "Tuberculosis and leprosy in antiquity: an interpretation,” Medical History, vol. 28, no. 2, pp. 162-173, 1984.

[10] T. Lietman, T. Porco, and S. Blower, "Leprosy and tuberculosis: the epidemiological consequences of cross-immunity," American Journal of Public Health, vol. 87, no. 12, pp. 1923-1927, 1997.
[11] S. Mazzi, Salute e Società Durante il Medioevo, La Nuova Editrice, Milan, Italy, 7th edition, 2010.

[12] C. Rawcliffe, Leprosy in Medieval England, Boydell Press, Woodbridge, UK, 2006.

[13] A. K. Wilbur, J. E. Buikstra, and C. Stajanowski, "Mycobacterial disease in North America: an epidemiological test of Chaussinand's cross-immunity hypothesis," in The Past and Present of Leprosy. Archaeological, Historical, Palaeopathological and Clinical Approaches, C. A. Roberts, M. E. Lewis, and K. Manchester, Eds., British Archaeological Reports International Series 1054, pp. 247-258, Oxford, UK, 2002.

[14] H. D. Donoghue, A. Marcsik, C. Matheson et al., "Coinfection of Mycobacterium tuberculosis and Mycobacterium leprae in human archaeological samples: a possible explanation for the historical decline of leprosy," Proceedings of the Royal Society B, vol. 272, no. 1561, pp. 389-394, 2005.

[15] C. D. Matheson, K. K. Vernon, A. Lahti et al., "Molecular exploration of the first-century tomb of the shroud in Akeldama, Jerusalem," PLoS ONE, vol. 4, no. 12, Article ID e8319, 2009.

[16] K. Ravindra, T. R. Sugareddy, and T. Ramachander, "Coexistence of borderline tuberculoid hansen's disease with tuberculosis verrucosa cutis in a child-a rare case," Indian Journal of Leprosy, vol. 82, no. 2, pp. 91-93, 2010.

[17] V. Mariotti, O. Dutour, M. G. Belcastro, F. Facchini, and P. Brasili, "Probable early presence of leprosy in Europe in a Celtic skeleton of the 4th-3rd century BC (Casalecchio di Reno, Bologna, Italy)," International Journal of Osteoarchaeology, vol. 15, no. 5, pp. 311-325, 2005.

[18] M. Rubini, "Disfiguring diseases and society in the 4rth-5th centuries A.D.: the case of Palombara Sabina (Rome, Central Italy)," in Proceedings of the Annual Meeting Archaeological Institute of America, Chicago, Ill, USA, 2008.

[19] M. Rubini, Y. S. Erdal, M. Spigelman, P. Zaio, and H. D. Donoghue, "Paleopathological and molecular study on two cases of ancient childhood leprosy from the Roman and Byzantine Empires," International Journal of Osteoarchaeology. In press.

[20] M. G. Belcastro, V. Mariotti, F. Facchini, and O. Dutour, "Leprosy in a skeleton from the 7th century necropolis of Vicenne-Campochiaro (Molise, Italy)," International Journal of Osteoarchaeology, vol. 15, no. 6, pp. 431-448, 2005.

[21] M. Rubini and P. Zaio, "Lepromatous leprosy in an early mediaeval cemetery in Central Italy (Morrione, Campochiaro, Molise, 6th-8th century AD)," Journal of Archaeological Science, vol. 36, no. 12, pp. 2771-2779, 2009.

[22] G. Fornaciari, F. Mallegni, and P. De Leo, "The leprosy of Henry VII: incarceration or isolation?" Lancet, vol. 353, no. 9154, p. 758, 1999.

[23] WHO, Global Leprosy Strategy Agreed for 2011-2015, 2011.

[24] J. E. Buikstra and D. H. Ubelaker, "Standards for Data Collection from Human Skeletal Remains," Archaeological Survey Research Series 44, 1994.

[25] T. W. Phenice, "A newly developed visual method of sexing the os pubis," American Journal of Physical Anthropology, vol. 30, no. 2, pp. 297-301, 1969.

[26] J. E. Buikstra and J. H. Mielke, "Demography, diet and health," in The Analysis of Prehistoric Diets, R. I. Gilbert and J.H. Mielke, Eds., pp. 359-422, Academic Press, New York, NY, USA, 1985.

[27] W. M. Krogman and M. Y. Iscan, The Human Skeleton in Forensic Medicine, Charles C. Thomas, Springfield, Ill, USA, 2nd edition, 1986. 
[28] A. Acsadi and J. Nemeskeri, History of Human Spain Life and Mortality, Akademiai Kiadò, Budapest, Hungary, 1970.

[29] S. T. Brooks and J. M. Suchey, "Skeletal age determination based on the os pubis: a comparison of the Acsadi-Nemeskeri and Suchey-Brooks methods," Human Evolution, vol. 5, no. 3, pp. 227-238, 1990.

[30] R. S. Meindl and C. O. Lovejoy, "Age changes in the pelvis: implication for paleodemography," in Age Markers in the Human Skeleton, Y. M. Iscan, Ed., pp. 137-168, Charles C. Thomas, Springfield, Ill, USA, 1989.

[31] R. S. Meindl and C. O. Lovejoy, "Ectocranial suture closure: a revised method for the determination of skeletal age at death based on the lateral-anterior sutures," American Journal of Physical Anthropology, vol. 68, no. 1, pp. 57-66, 1985.

[32] J. G. Andersen and K. Manchester, "The rhinomaxillary syndrome in leprosy: a clinical, radiological and paleopathological study," International Journal of Osteoarchaelogy, vol. 2, pp. 121-129, 1992.

[33] C. A. Roberts and K. Manchester, The Archaeology of Disease, Sutton Publishing, Gloucester, UK, 3rd edition, 2005.

[34] D. J. Ortner, Identification of Pathological Conditions in Human Skeletal Remains, Academic Press, New York, NY, USA, 2nd edition, 2003.

[35] S. L. Robbins and R. S. Cotran, Pathologic Basis of Disease, W.B. Saunders Company, Philadelphia, Pa, USA, 2002.

[36] J. Rogers and T. Waldron, "Infections in palaeopathology: the basis of classification according to most probable cause," Journal of Archaeological Science, vol. 16, no. 6, pp. 611-625, 1989.

[37] V. Møller-Christensen, "Evidence of leprosy in earlier people," in Disease in Antiquity. A Survey of Diseases, Injuries and Surgery, D. Brothwell and A. T. Sandison, Eds., pp. 295-306, Charles C. Thomas, Springfield, Ill, USA, 1967.

[38] P. Ruoppi, A. Dietz, E. Nikanne, J. Seppä, H. Markkanen, and J. Nuutinen, "Paranasal sinus mucormycosis: a report of two cases," Acta Oto-Laryngologica, vol. 121, no. 8, pp. 948-952, 2001.

[39] B. Rothschild, V. Naples, and L. Barbian, "Bone manifestations of actinomycosis," Annals of Diagnostic Pathology, vol. 10, no. 1, pp. 24-27, 2006.

[40] V. Møller-Christensen, "Storia della sifilide e della lebbra-Il punto di vista osteo-archeologico," Abbotempo, vol. 1, pp. 20 25, 1969.

[41] K. Manchester, "Infective bone changes in leprosy," in "The Past and Present of Leprosy. Archaeological, Historical, Paleopathological and Clinical Approaches, C. A. Roberts, M. E. Lewis, and K. Manchester, Eds., BAR International Series 1054, pp. 69-72, Oxford, UK, 2002.

[42] W. E. Bullock, "Mycobacterium leprae (leprosy)," in Principles and Practice of Infectious Diseases, G. L. Mandell, R. G. Douglas, and J. E. Bennett, Eds., pp. 1906-1914, Churchill Livingston, New York, NY, USA, 1990.

[43] D. M. Thappa, V. K. Sharma, S. Kaur, and S. Suri, "Radiological changes in hands and feet in disabled leprosy patients: a clinico-radiological correlation," Indian Journal of Leprosy, vol. 64, no. 1, pp. 58-66, 1992.

[44] C.A. Roberts, "The antiquity of leprosy in Britain: the skeletal evidence," in The Past and Present of Leprosy. Archaeological, Historical, Palaeopathological and Clinical Approaches, C. A. Roberts, M. E. Lewis, and K. Manchester, Eds., British Archaeological Reports International Series 1054, pp. 213-222, Oxford, UK, 2002.

[45] M. Rubini, "Salute e società durante il medioevo a Tusculum," in Lazio e Sabina, G. Ghini, Ed., vol. 4, pp. 157-160, De Luca Editore, Rome, Italy, 2007.
[46] M. Monot, N. Honoré, T. Garnier et al., "On the origin of leprosy," Science, vol. 308, no. 5724, pp. 1040-1042, 2005.

[47] L. L. Cavalli-Sforza, P. Menozzi, and A. Piazza, Storia e Geografia dei Geni Umani, Adelphi, Milan, Italy, 2nd edition, 2005.

[48] R. Stark, Gli Eserciti di Dio. Le Vere Ragioni Delle Crociate, Lindau Press, Turin, Italy, 2010. 


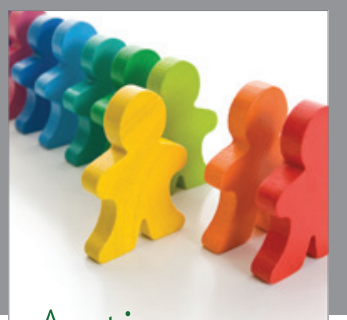

Autism

Research and Treatment
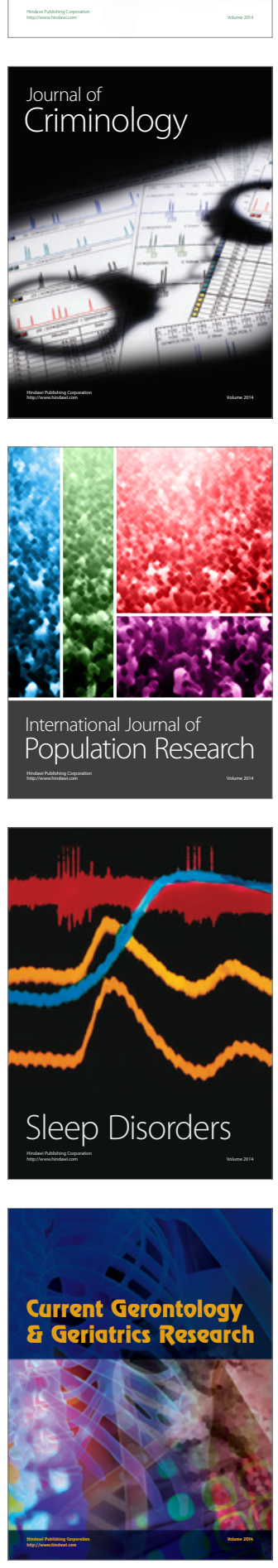
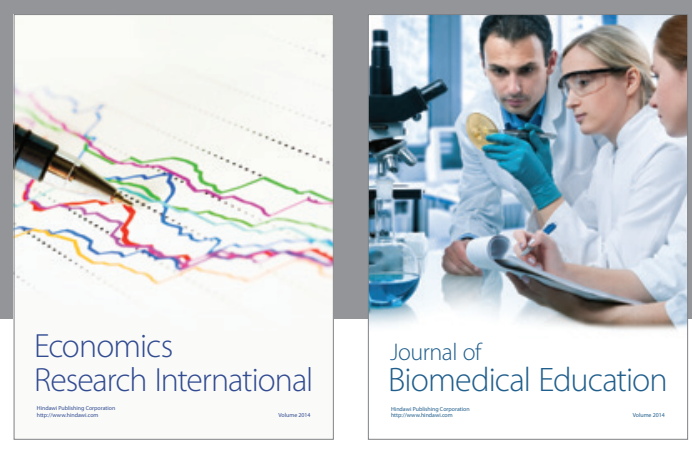

Journal of

Biomedical Education

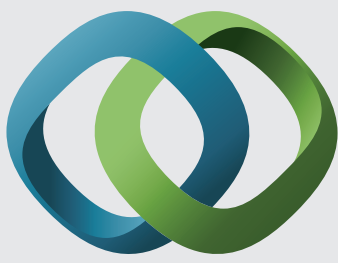

\section{Hindawi}

Submit your manuscripts at

http://www.hindawi.com
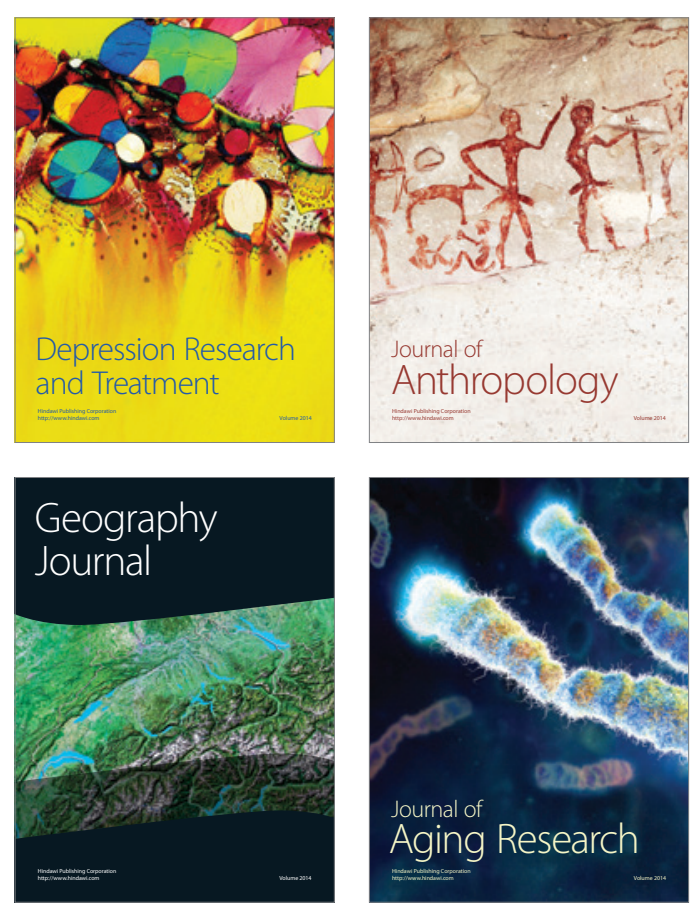

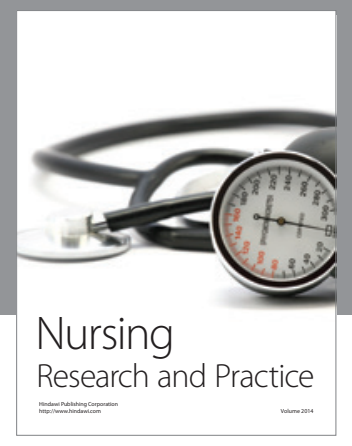

Nursing

Research and Practice

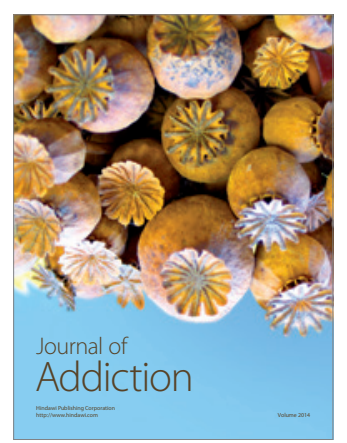

Child Development

Research

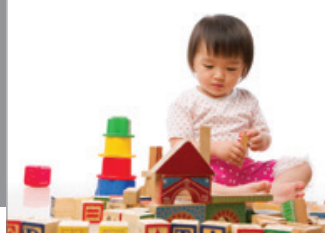

迥
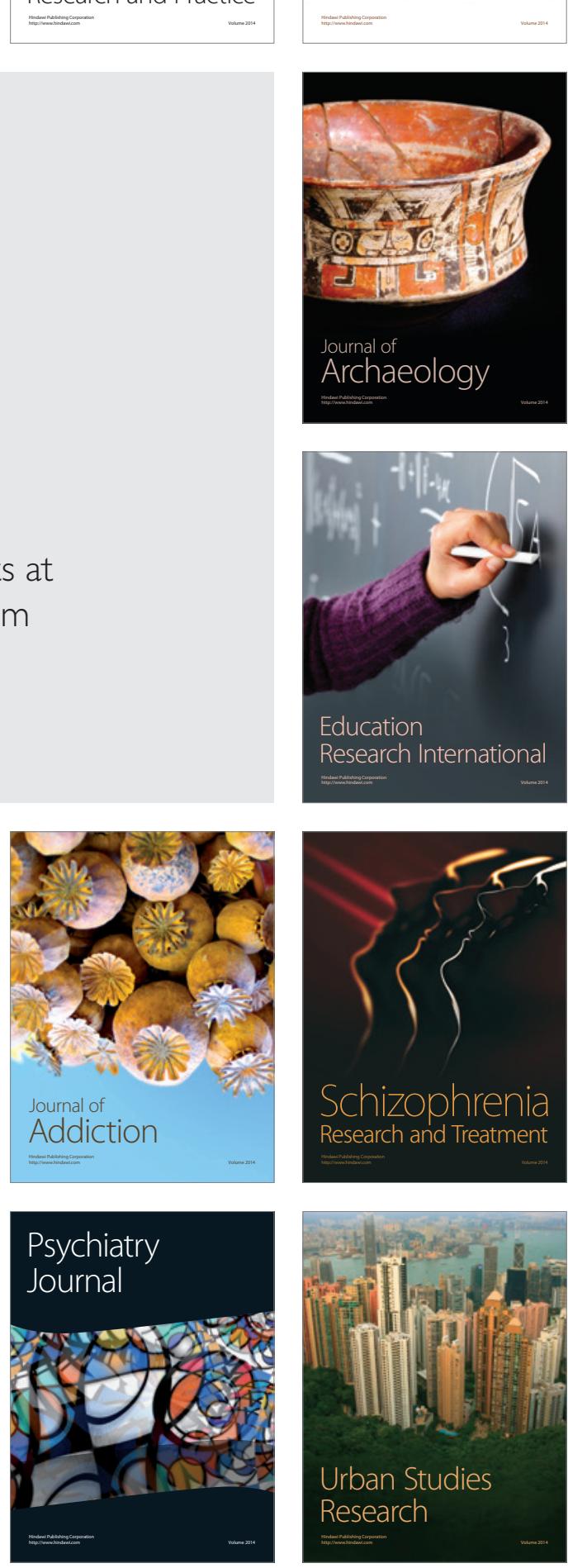